\title{
Development of Management Support System for Property Management Enterprises
}

\author{
Shih-Tong Lu',2, Jiun-Yi Shiu1, Dong-Shang Chang \\ ${ }^{1}$ Department of Banking and Finance, Real Estate and Risk Management Division, Kainan University, Taoyuan \\ County \\ ${ }^{2}$ Department of Business Administration, National Central University, Taoyuan County \\ Email: stonelu8604@gmail.com, jiunyi@mail.knu.edu.tw, changds@mgt.ncu.edu.tw
}

Received May 2014

\begin{abstract}
With the information technology developing, it makes the enterprises to use long-distance operation, video conference, intelligence management, electronic secretary, buildings automation, residents' communication platform and customer service system and so on. Application of these systems will also be the electronic trend for property management enterprises (PMEs). Owing to the competition in real estate market and large-scale buildings construction, the services and managements of the property are crucial to the future survival in this industry. Therefore, PMEs need to adopt advanced information technology such as facility management systems to promote their services quality, improve operation efficiency, reduce personnel cost and create professional image for achieving high competitive ability. This study is devoted to the service items for the development of a management support system (MSS). Based on the service items of property management identified through the literature review, a hierarchical structure of three dimensions and twenty sub-items is constructed, and a systematic approach with consistent fuzzy preference relations (CFPR) was employed to assess the relative importance and ranking of these items. Discussion of the results is made and a brief conclusion is proposed.
\end{abstract}

\section{Keywords}

Property Management Enterprise, Management Support System, Consistent Fuzzy Preference Relation

\section{Introduction}

With the development of information technology and internet, the technology of information management has been involved in every industry. From public administration units to private enterprises, manufacturing industry to service industry, people can enjoy the convenience of the application of the information technology. Since the evolutions of technology of real estate and building are more mature, this also induces the demand of property 
management to increase. Therefore, property management for buildings has become a very important and closely related industry with residents because the extents and benefits of direct relationship with public are more than in other industries. These make the development of management support systems (MSS) and provide its services for property management more urgent. According to the experiences of industry evolution of developed countries, the property management services in Taiwan and China will have very good opportunity to become a prosperous industry for implementing and adopting the MSS effectively. This study is to explore and realize the characteristic of property management and the needs of MSS for property management enterprises (PMEs). Then we apply the multiple attributes decision analysis (MADA) approach, consistent fuzzy preference relation (CFPR) which proposed by [1], to analyze the priority of key items of MSS. It can provide a good reference to PMEs or systems development companies in design of decision support system.

\section{Research Method and Process}

\subsection{Identifying the Key Items of MSS of Property Management}

For the extent of services providing of a PME, the Council for Economic Planning and Development [2] pointed out that the property management refer to provide maintenance management and comprehensive operations services based on hardware of building and software of community and living environment. It divided property management into three categories, including the usage management and maintenance of the buildings and the environment, the support services of life and business activities and asset management services. It is shown that the PME belong to a kind of integrated industry, and its operating items are really complicated. The power supply, water supply, gas, fire, sanitation and security of buildings are covered within its scope of business. Therefore, the methods of professional business subcontracting and strategic alliance management are widely used by PMEs. Form this definition, the service scope of property management industry is quite broad, and no longer only limited to maintenance work on buildings, and even includes the various relative support services on residents' living.

According to literature reviews of [3]-[9], this study aggregates a complete service items of PMEs should include the construction management services before the building is constructed, building management services and business support services after the building construction completed, and each of categories have six to eight items, and all functions are described as follows as shown in Table $\mathbf{1 .}$

Based on the hierarchical structure of Table 1, we apply pairwise comparison approach to measure the relative importance of each item for realizing the relative importance of each service item in systems development process. The most famous pairwise comparison approach is analytical hierarchical process (AHP) which developed by [10]. However, when evaluation items are more than seven, the AHP approach will become very complicate and it is not easy to maintain the judgments consistency of evaluators in evaluation processes. Reference [1] proposed the CFPR approach which can simplify and improve the problem of consistency of the AHP in more criteria or alternatives. In the traditional AHP comparisons, if the assessment has $n$ items, pairwise comparisons should be conducted for $n(n-1) / 2$ times. Reference [1] proposed the CFPR to simplify the comparison process to $n-1$ times and obtain the corresponding relative weightings. The benefits of using this approach include not only the simplification of the questionnaires design and collection, but also preserved consistency of respondent's preference. This approach also saves time to investigate the consistency on data collections. This approach shows great advantages on efficiency and effectiveness especially when more criteria/alternatives are assessed. The concept and steps of using the CFPR is presents as the following subsection.

\subsection{Consistent Fuzzy Preference Relations}

The consistent fuzzy preference relations were proposed for constructing the decision matrices of pairwise comparisons based on additive transitivity [1]. Fuzzy preference relations require a decision maker to assign values for a set of criteria. The value represents the degree of the preference for a criterion over another criterion.

\subsection{Multiplicative Preference Relations}

Matrix $\boldsymbol{A} \subset \boldsymbol{X} \times \boldsymbol{X}$ shows the multiplicative preference relations of $\boldsymbol{X}$ criterion/alternative centers on $\boldsymbol{A}$, where $\boldsymbol{A}=\left[a_{i j}\right], a_{i j}$ is the preference intensity ratio of criterion/alternative $x_{i}$ to criterion/alternative $x_{j}$. Reference [10] suggested $a_{i j}$ to be scaled from 1 to 9 . Herein, $a_{i j}=1$ represents the existence of no difference 
Table 1. The service items of property management.

\begin{tabular}{|c|c|c|}
\hline $\begin{array}{l}\text { Service } \\
\text { Dimension }\end{array}$ & Service Items & Descriptions \\
\hline \multirow{6}{*}{$\begin{array}{l}\text { Construction } \\
\text { Management } \\
\text { Services }\end{array}$} & Fund-raising services of real estate and land & $\begin{array}{l}\text { Land, buildings and other immovable property } \\
\text { lending financial services }\end{array}$ \\
\hline & Building planning and design services & $\begin{array}{l}\text { Property-related facilities planning and design } \\
\text { services for the construction of buildings }\end{array}$ \\
\hline & Interior design and planning services & $\begin{array}{l}\text { The building cases in door facilities, decor, } \\
\text { design and planning service }\end{array}$ \\
\hline & Energy management services & $\begin{array}{c}\text { Management services of water, electricity, gas and other } \\
\text { energy-saving or planning }\end{array}$ \\
\hline & Construction project management services & $\begin{array}{l}\text { Management services of water, electricity, gas and } \\
\text { other energy-saving or planning }\end{array}$ \\
\hline & Building renewal/maintenance planning services & Undertake old building renovation and maintenance planning \\
\hline \multirow{8}{*}{$\begin{array}{l}\text { Building } \\
\text { Management } \\
\text { Services }\end{array}$} & The lease planning and marketing & Planning and marketing operations of buildings pace lease \\
\hline & Administrative and accounting tasks & $\begin{array}{l}\text { Buildings administrative management operations and } \\
\text { accounting tasks }\end{array}$ \\
\hline & Cleaning and maintenance of public facilities & Building cleaning and maintenance of public facilities management \\
\hline & Landscape planning & $\begin{array}{c}\text { Inside the building or the surrounding greenery and landscape } \\
\text { planning, design and implementation }\end{array}$ \\
\hline & The structure of the building maintenance & $\begin{array}{c}\text { Maintenance of the structural safety of the building itself and the } \\
\text { surrounding structure or appearance }\end{array}$ \\
\hline & Subsistence system management & $\begin{array}{l}\text { Maintenance and management of building water supply, } \\
\text { fire, generator, air conditioning, elevators, etc. }\end{array}$ \\
\hline & Security management services & $\begin{array}{l}\text { The buildings surrounding households portal lanes and } \\
\text { out of security maintenance and management }\end{array}$ \\
\hline & Recreational facilities Management & $\begin{array}{l}\text { Recreational facilities within the building maintenance } \\
\text { and management }\end{array}$ \\
\hline \multirow{6}{*}{$\begin{array}{l}\text { Business Support } \\
\quad \text { Services }\end{array}$} & Legal advisory services & Household legal advisory services \\
\hline & Financial planning services & $\begin{array}{l}\text { Household financial management, tax consulting, } \\
\text { insurance planning, financial services }\end{array}$ \\
\hline & Marketing and leasing services & Housing consignment, leasing and advertising services \\
\hline & Administrative resources services & $\begin{array}{l}\text { General building (commercial buildings), } \\
\text { General Services, for example: Procurement }\end{array}$ \\
\hline & Accounting services & $\begin{array}{l}\text { The escrow accounting service commercial households or } \\
\text { general households }\end{array}$ \\
\hline & Logistics delivery services & $\begin{array}{l}\text { Building set of home delivery, enhance households } \\
\text { send something convenience }\end{array}$ \\
\hline
\end{tabular}

between criterion/alternative $x_{i}$ and $x_{j}, a_{i j}=9$ manifests that $x_{i}$ is absolutely important compared to $x_{j}$. In this case, the preference relation is typically assumed to be a multiplicative reciprocal:

$$
a_{i j} \cdot a_{j i}=1 \quad \forall i, j \in\{1, \cdots, n\}
$$

\subsection{Fuzzy Preference Relations}

The fuzzy preference relation $\boldsymbol{P}$ on a set of criteria/alternatives $\boldsymbol{X}$ is a fuzzy set of the product $\boldsymbol{X} \times \boldsymbol{X}$ with membership function $\mu_{p}: \boldsymbol{X} \times \boldsymbol{X} \rightarrow[0,1]$. The preference relation is represented by the matrix $\boldsymbol{P}=\left[p_{i j}\right]$, where $p_{i j}=\mu_{p}\left(x_{i}, x_{j}\right)$. Herein, $p_{i j}$ is interpreted as the level of influence ratio of criterion/alternative $x_{i}$ over $x_{j}$. If $p_{i j}=1 / 2$, it means that $x_{i}$ and $x_{j}$ are equally important/good (i.e. $x_{i} \sim x_{j}$ ); $p_{i j}=1$ indicates that $x_{i}$ is absolutely important/preferred to $x_{j} ; p_{i j}=1 / 2$ shows that $x_{i}$ is more important/preferred to $x_{j}$, i.e. $x_{i} \succ x_{j}$. In this case, the preference matrix, $\boldsymbol{P}$, is usually assumed additive reciprocal, i.e., 


$$
p_{i j}+p_{j i}=1 \quad \forall i, j \in\{1, \cdots, n\}
$$

\subsection{Consistent Fuzzy Preference Relations}

A set of alternatives $x=\left\{x_{1}, \cdots, x_{n}\right\}$ and $\boldsymbol{x} \in X$ is associated with a reciprocal multiplicative preference relations $\boldsymbol{A}=\left[a_{i j}\right]$ for $a_{i j} \in[1 / 9,9]$. Then, $a_{i j}$ can use Equation (3) to obtain the corresponding reciprocal fuzzy preference relation $\boldsymbol{P}=\left[p_{i j}\right]$ for $p_{i j} \in[0,1]$ associated with $\boldsymbol{A}$ :

$$
p_{i j}=g\left(a_{i j}\right)=\frac{1}{2}\left(1+\log _{9} a_{i j}\right)
$$

Herein, $\log _{9} a_{i j}$ is considered because $a_{i j}$ is between $1 / 9$ and 9 . When the reciprocal fuzzy preference relation $\boldsymbol{P}=\left[p_{i j}\right]$ is additive consistency, there exist the relationships as Equation (4) and (5):

$$
\begin{gathered}
p_{i j}+p_{j k}+p_{k i}=\frac{3}{2} \quad \forall i<j<k \\
p_{i(i=1)}+p_{(i+1)(i+2)}+\cdots+p_{(j-1) j}=(j-i+1) / 2 \quad \forall i<j
\end{gathered}
$$

\subsection{Determining the Relative Importance of Evaluation Items}

When we obtain the $n-1$ preference intensity ratio $\left\{a_{12}, a_{23}, \cdots, a_{n-1, n}\right\}$ of criteria/alternative $\boldsymbol{x}=\left\{x_{1}, \cdots, x_{n} \mid n \geq 2\right\}$ from experts' judgments, Formula (3) can be used to construct a fuzzy preference relation for the set of $n-1$ values $\left\{p_{12}, p_{23}, \cdots, p_{n-1, n}\right\}$. Then the other preference relations values of the decision matrix, $\boldsymbol{B}=\left\{\left.p_{i j}\right|_{i<j} p_{i j} \notin\left\{p_{12}, p_{23}, \cdots, p_{n-1, n}\right\}\right\}$, will be obtained by the Formulae (2), (4) and (5). However, after this calculation, all the necessary elements in the decision matrix $\boldsymbol{P}$ may really not all lie within $[0,1]$ but will lie within $[-a, 1+a]$, where $a=\left|\min \left\{\boldsymbol{B} \cup\left\{p_{12}, p_{23}, \cdots, p_{n-1, n}\right\}\right\}\right|$. Therefore, it can be obtained the consistent reciprocal fuzzy preference relation matrix $\mathbf{P}^{\prime}$ by the transformation function $\boldsymbol{P}^{\prime}=f(p)$. This process can make the decision matrix maintaining reciprocity and additive consistency. The transformation function is as following:

$$
f:[-a, 1+a] \rightarrow[0,1], f(x)=(x+a) /(1+2 a)
$$

\subsection{Integrated the Experts' Judgments}

The pairwise comparison of sequentially adjoining is constructed by expert $k$ with respect to evaluation item $n$, that is $\left\{a_{12}^{k}, a_{23}^{k}, \cdots, a_{n-1, n}^{k}\right\}$, then they have to transform $a_{i j}^{k}$ to $p_{i j}^{k}$ by the Equation (3). When there are $m$ evaluators, it needs to use geometric mean for mitigating the extreme values. Therefore, the integration formula is shown as following:

$$
\bar{p}_{i j}=\left(p_{i j}^{1} \times p_{i j}^{2} \cdots \times p_{i j}^{m}\right)^{1 / m} \quad i<j \quad \forall i, j \in\{1, \cdots, n\}
$$

Then, we can apply the Equations (1) to (6) to obtain the integrated consistent reciprocal relation matrix $\overline{\boldsymbol{P}}^{\prime}=\left(\bar{p}_{i j}^{\prime}\right)$. Finally, it utilizes the normalization of row vector average method proposed by [11] to obtain the integrated weights of each evaluation item $i, w_{i}$, as in following equation:

$$
D_{i}=\left(\sum_{j=1}^{n} \bar{p}_{i j}^{\prime}\right) / n, \quad w_{i}=D_{i} / \sum_{i=1}^{n} D_{i}
$$

The evaluation results can be used to determine the priority of the MSS development items on property management services. In addition, information system developers or companies could recognize the relative importance of service items of PMEs to determine appropriate systems development strategies.

\section{Results of Case Study}

In order to investigate the priority of the MSS development of service items for property management in Table 1, fourteen industry experts, each with more than ten years' working experience on PMEs, were interviewed to evaluate the relative importance for pairwise service items of property management. A reciprocal multiplicative pre- 
ference relation matrix of relative importance for the listed service items was obtained from each of experts' interviews. The reciprocal multiplicative preference relation matrix was then computed using Equations (3)-(6) to obtain a consistent fuzzy preference relations matrix and further use Equation (7) and (8) to determine the integrated weights of service items of property management. The relative importance and ranking of service dimensions and service items of PMEs should provide are displayed in Table 2.

Among the identified three dimensions, "Building Management Services" was considered as the most important dimension to offer the services for residents or users of building by PMEs. "Construction Management Services" and "Business Support Services" are the second and third important dimensions to improve service performance of property management respectively.

For the "Building Management Services" dimension, the "Administrative and accounting tasks" has the highest relative importance among eight service items. "The lease planning and marketing”, "Security management services", and "Cleaning and maintenance of public facilities" are another three service items with higher relative importance among eight service items in this group. These results imply the PME is in great need to use MSS for administrative activities and accounting treatments of the company and the clients (condominium management committees).

Among the "Construction Management Services" dimension, "Energy management services" is considered as the most important service item. "Building planning and design services" is another with higher important service item to management performance in this dimension. However, "Fund-raising services of real estate and land" is the least important service item in this group. In addition, for the "Business Support Services" dimension, "Accounting services" and "Administrative resources services" are the two most important service items

Table 2. The weights and rankings of service items of property management.

\begin{tabular}{|c|c|c|c|c|}
\hline $\begin{array}{c}\text { Service } \\
\text { Dimension }\end{array}$ & Weights & Service Items & Weights & Rankings \\
\hline \multirow{5}{*}{$\begin{array}{c}\text { Construction Management } \\
\text { Services }\end{array}$} & \multirow{6}{*}{0.3357} & Fund-raising services of real estate and land & 0.1313 & 6 \\
\hline & & Building planning and design services & 0.1777 & 2 \\
\hline & & Interior design and planning services & 0.1578 & 5 \\
\hline & & Energy management services & 0.1947 & 1 \\
\hline & & Construction project management services & 0.1689 & 4 \\
\hline \multirow{9}{*}{$\begin{array}{c}\text { Building Management } \\
\text { Services }\end{array}$} & & Building renewal/maintenance planning services & 0.1695 & 3 \\
\hline & \multirow{8}{*}{0.3966} & The lease planning and marketing & 0.1375 & 2 \\
\hline & & Administrative and accounting tasks & 0.1567 & 1 \\
\hline & & Cleaning and maintenance of public facilities & 0.1337 & 4 \\
\hline & & Landscape planning & 0.1053 & 7 \\
\hline & & The structure of the building maintenance & 0.1206 & 6 \\
\hline & & Subsistence system management & 0.1224 & 5 \\
\hline & & Security management services & 0.1372 & 3 \\
\hline & & Recreational facilities Management & 0.0866 & 8 \\
\hline \multirow{6}{*}{ Business Support Services } & \multirow{6}{*}{0.2677} & Legal advisory services & 0.1636 & 3 \\
\hline & & Financial planning services & 0.1520 & 5 \\
\hline & & Marketing and leasing services & 0.1428 & 6 \\
\hline & & Administrative resources services & 0.1826 & 2 \\
\hline & & Accounting services & 0.2006 & 1 \\
\hline & & Logistics delivery services & 0.1584 & 4 \\
\hline
\end{tabular}


among this six service items. This result indicates the PME can use the MSS to assist the residents to deal with the bookkeeping affairs or general affairs of their private business.

\section{Conclusion}

This study adopted CFPR process model, proposed by [1], to determine the relative importance of the twenty service items associated with property management on operation and management performance of buildings. The implementation of CFPR could benefit on the reduction of required pairwise comparisons, facilitate the development and response of survey questionnaire and remain the consistency of pairwise comparisons. The investigation results indicate that the most urgent information modules are "Administrative and accounting tasks", "The lease planning and marketing", "Security management services" and "Cleaning and maintenance of public facilities " in initiative of the PMEs conducting e-formalization, MSS development or software procurement. If the PMEs would like to extend the ability and extent of services, it should reinforce the MSS involving the modules of construction management services and business support services.

\section{References}

[1] Herrera-Viedma, E., Herrera, F., Chiclana, F. and Luque, M. (2004) Some Issues on Consistency of Fuzzy Preference Relations. European Journal of Operational Research, 154, 98-109. http://dx.doi.org/10.1016/S0377-2217(02)00725-7

[2] Council for Economic Planning and Development (2004) Programme and Action of Service Industries Development. Council for Economic Planning and Development, Taipei.

[3] Kyle, R.C. and Baird, F.M. (1991) Property management, Fourth Edition, Real Estate Education Company, Chicago.

[4] Shear, M.A. (1988), Property Management Reinvented: How to Convert Maintenance and Energy Expenses to Profits, Prentice-Hall, Englewood-Cliffs.

[5] Arabe, K.C. (2003), 7 Major Trends in Facilities Management. http://news.thomasnet.com/kwsearch.html

[6] Chen, B.T. (2004) A Fundamental Study on Property Management Intension in Taiwan (Taipei). Master Thesis, Taipei University, Taiwan.

[7] Lin, Z.C., Kuo, Y.C. and Huang, C.N. (2007) The Development Profile of Property Management Industry in Taiwan. Proceedings of the 1st Conference on Property Management of Taiwan, Taiwan Institute of Property Management, Taipei, II-1-13-24.

[8] Lu, S.T., Lin, Z.C. and Kuo, Y.C. (2007) The Present and Future Trends of Global Property Management Industry. Proceedings of the 1st Conference on Property Management of Taiwan, Taiwan Institute of Property Management, Taipei, II-1-1-12.

[9] Huang, C.T., Lu, S.T, Sun, K.S. and Ku, H.K. (2011) The Exploration for Development Strategies of Property Management. Journal of Logistics Management, 10, 31-49.

[10] Saaty, T.L. (1980) The Analytic Hierarchy Process, McGraw-Hill, New York.

[11] Wang, T.C. and Chen, Y.H. (2008) Applying Fuzzy Linguistic Preference Relations to The improvement of Consistency of Fuzzy AHP. Information Sciences, 178, 3755-3765. http://dx.doi.org/10.1016/j.ins.2008.05.028 